\title{
Influences of $\alpha$-tocopherol on cholesterol metabolism and fatty streak development in apolipoprotein E-deficient mice fed an atherogenic diet
}

\footnotetext{
M.C.G. Peluzio ${ }^{1}$

A.P.P. Homem ${ }^{1}$,

G.C. Cesar ${ }^{1}$, G.S. Azevedo ${ }^{1}$,

R. Amorim ${ }^{1}$, D.C. Cara ${ }^{2}$,

H. Saliba ${ }^{3}$,

E.C. Vieira ${ }^{1}$, R.E. Arantes ${ }^{2}$

and J. Alvarez-Leite ${ }^{1}$
}

\author{
1Departamento de Bioquímica e Imunologia, and \\ 2Departamento de Patologia, Instituto de Ciências Biomédicas, \\ Universidade Federal de Minas Gerais, Belo Horizonte, MG, Brasil \\ ${ }^{3}$ Departamento de Nutrição, Escola de Veterinária, \\ Universidade Federal de Minas Gerais, Belo Horizonte, MG, Brasil
}

\section{Correspondence \\ J. Alvarez-Leite \\ Departamento de Bioquímica e \\ Imunologia, ICB, UFM G \\ Caixa Postal 486 \\ 30161-970 Belo Horizonte, MG \\ Brasil \\ Fax: + 55-31-441-5963 \\ E-mail: alvarez@mono.icb.ufmg.br \\ Research supported by CNPq and CAPES. E.C. Vieira, R.E. Arantes \\ and J.I. Alvares-Leite are \\ recipients of research fellowships \\ from CNPq. A.P.P. Homem and \\ M.C.G. Peluzio are recipients \\ of graduate fellowships from CAPES. \\ Scientific training fellowships were \\ granted to G.C. Cesar by CNPq and \\ to R. Amorim and G.S. Azevedo by \\ FAPEMIG.}

Received June 25, 2001

Accepted September 12, 2001

\section{Abstract}

Although the role of oxidized lipoproteins is well known in atherogenesis, the role of vitamin E supplementation is still controversial. There is also little information about cholesterol metabolism (hepatic concentration and fecal excretion) in the new models of atherosclerosis. In the present study, we evaluated the effect of moderate vitamin E supplementation on cholesterol metabolism and atherogenesis in apolipoprotein E (apo E)-deficient mice. Apo E-deficient mice were fed an atherogenic diet containing 40 or $400 \mathrm{mg} / \mathrm{kg}$ of $\alpha$-tocopherol acetate for 6 weeks. Total cholesterol in serum and liver and 3-OH- $\alpha-$ sterols in feces, and fecal excretion of bile acids were determined and histological analyses of aortic lesion were performed. A vitamin Erich diet did not affect body weight, food intake or serum cholesterol. Serum and hepatic concentrations of cholesterol as well as sterol concentration in feces were similar in both groups. However, when compared to controls, the $\alpha$-tocopherol-treated mice showed a reduction of about $60 \%$ in the atherosclerotic lesions when both the sum of lesion areas and the average of the largest lesion area were considered. These results demonstrate that supplementation of moderate doses of $\alpha$-tocopherol was able to slow atherogenesis in apo E-deficient mice and to reduce atherogenic lipoproteins without modifying the hepatic pool or fecal excretion of cholesterol and bile acids.

\section{Introduction}

Atherosclerosis is one of the major causes of morbidity, disability and premature mortality in industrialized countries. The oxidative hypothesis postulates that the presence and accumulation of oxidized low-density

\section{Key words}

- Antioxidants

- Atherosclerosis

- Apo E

- Mice

- $\alpha$-Tocopherol

- Cholesterol lipoproteins (LDL) in the subendothelium start a cascade of a complex sequence of events that can culminate in atheroma development $(1,2)$. Human consumption of food rich in antioxidants is associated with a lower risk of atherosclerosis $(3,4)$. Dietary antioxidants such as vitamin $C$, vitamin $E$, $ß$-caro- 
tene, flavonoids, isoflavonoids and organosulfur compounds protect LDL against in vitro oxidation (5).

Vitamin $\mathrm{E}$ is a non-enzymatic antioxidant present in plasma and cells that neutralizes free radicals. In ex-vivo experiments, supplementation with $\alpha$-tocopherol significantly reduced the copper-mediated oxidation of human LDL (6). However, the reduction of atherosclerotic lesions by vitamin $\mathrm{E}$ in experimental models is still controversial (7-10). There is little knowledge of the mechanisms involved in this protection as well as of the levels of vitamin E necessary. The doses of vitamin E administered (800-2000 IU/kg of diet or 40 to 100 times higher than the recommendation for mice) in most of the experimental studies are higher than those used for human supplementation (400-800 IU/day). Few studies have tested the effects of vitamin $\mathrm{E}$ supplementation at lower concentrations. The amount supplemented in our study was about 20 times higher than the recommendation for mice and equivalent to a human intake of 200 IU/day. We believe that the results obtained with this level of supplementation will be closer to those obtained with the usual human supplementation.

The use of apolipoprotein E (apo E)deficient mice in this study is justified because they develop lesions similar to those seen in humans and this animal model has been well accepted as an important tool to observe the effects of vitamin E not only on cholesterolemia but also on the evolution of plaques in different stages of the lesion.

The aim of the present study was to evaluate the rate of development of atherosclerotic lesions in apo E-deficient mice supplemented with moderate doses of vitamin $\mathrm{E}$ for short periods of time.

\section{Material and Methods}

\section{Animals and experimental design}

The homozygous apo E-deficient $\left(\mathrm{apoE}^{-/}\right)$ mice (of C57BL/6 background) $(11,12)$ were purchased from Jackson Laboratory (Bar Harbor, ME, USA) and kept in the animal facility of Instituto de Ciências Biológicas, UFMG, Belo Horizonte, MG, Brazil. Forty 7-week-old apoE $\mathrm{E}^{-/-}$mice were used in this experiment. ApoE ${ }^{-/-}$mice were fed a control $\operatorname{diet}(\mathrm{N}=20)$ or an $\alpha$-tocopherol-rich $\operatorname{diet}(\mathrm{N}$ $=20)$ for 6 weeks. The animals were distributed based on their initial weight $(16.5 \pm 1 \mathrm{~g})$ and initial serum cholesterol $(470 \pm 60 \mathrm{mg} /$ $\mathrm{dl})$. The mice were housed in groups of 4-6 in plastic cages and kept in a room with a controlled 12:12-h light/dark cycle. Free access to food and water was provided. The basic composition $(\mathrm{g} / 100 \mathrm{~g})$ of the atherogenic diet was: sucrose (50.2), casein (20), lard (15), salt mixture (5), cellulose (5), vitamin mixture (1), soybean oil (1), choline (1), cholesterol (1), cholic acid (0.5), and methionine (0.3). $\alpha$-Tocopherol acetate (20 and $400 \mathrm{mg} / \mathrm{kg}$ ) was added to the control and tocopherol-rich diets, respectively. The diets were prepared every two weeks and stored in the dark at $-4^{\circ} \mathrm{C}$. Individual body weights were recorded weekly. At the end of the experiment, the animals were fasted for $8 \mathrm{~h}$ and killed under ether anesthesia. Blood was collected from the orbital plexus and serum was stored in a nitrogen atmosphere. Serum was frozen at $-70^{\circ} \mathrm{C}$ for further tocopherol determination. The aorta was removed from the root in the heart to the iliac bifurcation and fixed for histopathological analysis. The liver was removed, weighed and frozen at $-20^{\circ} \mathrm{C}$. Feces collected during the last seven days of the experimental period were pooled, dried, weighed and powdered.

\section{Analytical methods}

Blood samples were centrifuged at 12,000 $g(3,500 \mathrm{rpm})$ for $10 \mathrm{~min}$ and the sera were used for cholesterol determination on the same day. For tocopherol determination, sera were kept in a $\mathrm{N}_{2}$ atmosphere and stored at $-7^{\circ} \mathrm{C}$. Total vitamin $\mathrm{E}$, tocopherols and 
tocotrienols in the diets and $\alpha$-tocopherol in the serum were determined by high-performance liquid chromatography (13).

Total cholesterol in serum (14) and liver and 3-OH- $\alpha$-sterols in feces were determined enzymatically using commercial kits (Katal, Belo Horizonte, MG, Brazil). Sera from apoE $^{-/-}$mice were diluted $1: 10$ in $0.85 \% \mathrm{NaCl}$ before cholesterol determination to keep the absorbance within the proper range of the test.

Fecal bile acids were extracted by the method of van der Meer et al. (15) and the supernatants were enzymatically assayed as previously described (16). Hepatic and fecal total lipids were extracted by the method of Folch et al. (17), gravimetrically quantified, resuspended in isopropanol and assayed for total cholesterol.

The heart and proximal section of the aorta were removed from the animals and cleaned of adventitial tissue. The top half of the hearts was obtained under stereoscopic observation and fixed by immersion in $4 \%$ paraformaldehyde in $0.1 \mathrm{M}$ phosphate-buffered saline at room temperature. The specimens were routinely processed for paraffin embedding and histological sections were examined under a light microscope by one individual who did not have access to the codes. The entire specimen was analyzed (250 sections per mouse). The aortic root area was recognized by the proximal presence of aortic valve leaflets. Every consecutive section ( $5 \mu \mathrm{m}$ thick) throughout the aortic root area $(300 \mu \mathrm{m}$ - 60 sections per mouse) was taken for analysis and stained with hematoxylin and eosin. Of every five sections, one was kept for morphometric analysis using an image analyzer (KS 300 program) attached to a microcamera and Zeiss microscope.

The lesion area of each animal represents the sum of the lesion area obtained from the ten sections analyzed.

In a second experiment, fourteen $4-\mu \mathrm{m}$ aortic sections (from aortic root) separated by $200-\mu \mathrm{m}$ intervals were obtained and stained with hematoxylin-eosin. Morphological and morphometric analysis was performed using the average of the three largest lesion areas from each animal.

\section{Statistical analysis}

The Student $t$-test was used to compare independent values. $\mathrm{P}<0.05$ was accepted as statistically significant.

\section{Results}

There were no differences in final body weight or total food intake between groups (data not shown). The concentration of $\alpha$ tocopherol was nearly ten times higher in the experimental diet than that in the control diet (Table 1). As expected, $\alpha$-tocopherol was the major component of total vitamin $\mathrm{E}$ in both diets. $\alpha$-Tocopherol levels were twofold higher in serum of animals receiving the $\alpha$-tocopherol-enriched diet than in controls (Table 1).

At the end of the experiment, $\mathrm{apoE}^{-/-}$ mice fed the control and $\alpha$-tocopherol diets had similar serum cholesterol levels (Table 2). No significant differences were found in total lipid, triacylglycerol (data not shown) or cholesterol concentrations in liver (Table 2). Histopathological analysis showed similar fat accumulation in livers of both groups (data not shown).

Hepatic cholesterol and fecal bile acid and $3-\mathrm{OH}-\alpha$-sterols were determined to investigate if the reduction of plasma choles-

Table 1. Dietary tocopherols and serum $\alpha$-tocopherol of apoE-1- mice fed an atherogenic diet containing $40 \mathrm{lU} / \mathrm{kg}$ (control) or $400 \mathrm{lU} / \mathrm{kg} \alpha$-tocopherol acetate for 6 weeks.

\begin{tabular}{lcc}
\hline & Control group & $\alpha$-Tocopherol group \\
\hline$\alpha$-Tocopherol (mg/kg of diet) & $38.1 \pm 3.6$ & $360.2 \pm 18.8$ \\
ß-Tocopherol (mg/kg of diet) & $0.5 \pm 0.0$ & $0.5 \pm 0.0$ \\
$\gamma$-Tocopherol (mg/kg of diet) & $6.6 \pm 0.3$ & $21.0 \pm 0.7$ \\
$\delta$-Tocopherol (mg/kg of diet) & $<0.1$ & $<0.1$ \\
Vitamin E (IU/kg of diet) & 40 & 400 \\
Serum $\alpha$-tocopherol (mg/dl) & 1.22 & 2.28
\end{tabular}


terol in the $\alpha$-tocopherol group was due to an alteration in cholesterol catabolism. Since sitosterols are not important components of our atherogenic diet, the concentrations of 3$\mathrm{OH}-\alpha$-sterols reflect concentrations of cholesterol and its catabolic products in feces. No differences were observed in hepatic or fecal parameters (Table 2).

Atherosclerotic lesions were found in both groups. However, the control group had

Table 2. Serum and hepatic cholesterol, fecal 3-OH- $\alpha$-sterols and bile acids of apoE $\mathrm{E}^{-1-}$ mice fed atherogenic diets containing $40 \mathrm{IU} / \mathrm{kg}$ (control) or $400 \mathrm{IU} / \mathrm{kg} \alpha$-tocopherol acetate for 6 weeks.

\begin{tabular}{|c|c|c|}
\hline & Control group & $\alpha$-Tocopherol group \\
\hline Serum cholesterol $(\mathrm{mg} / 100 \mathrm{ml})^{*}$ & $2593 \pm 172$ & $2274 \pm 249$ \\
\hline Hepatic cholesterol (mg/g liver) ${ }^{*}$ & $24.12 \pm 2.65$ & $18.74 \pm 1.58$ \\
\hline Fecal bile acids ( $\mu \mathrm{mol} / \mathrm{g}$ feces) ${ }^{+}$ & $23.15 \pm 7.90$ & $11.50 \pm 1.25$ \\
\hline Fecal 3-OH- $\alpha$-sterols (mg/g feces) ${ }^{+}$ & $40.35 \pm 3.80$ & $47.50 \pm 1.75$ \\
\hline
\end{tabular}

*Mean \pm SEM of individual values $(\mathrm{N}=18)$.

+ Mean \pm SEM of 3 pooled samples.

Figure 1. Average of the largest lesion area $(A)$ or of the sum of the atherosclerotic lesion $(B)$ in the proximal aorta of $\mathrm{apoE}^{-/-}$ mice fed diets containing $40 \mathrm{IU} /$ $\mathrm{kg}$ (control) or $400 \mathrm{lU} / \mathrm{kg} \alpha$-tocopherol acetate for 6 weeks. Circles represent individual measurements and bars represent the average of each group. For details see Material and Methods. * $\mathrm{P}<0.05$ compared to control group (Student t-test).

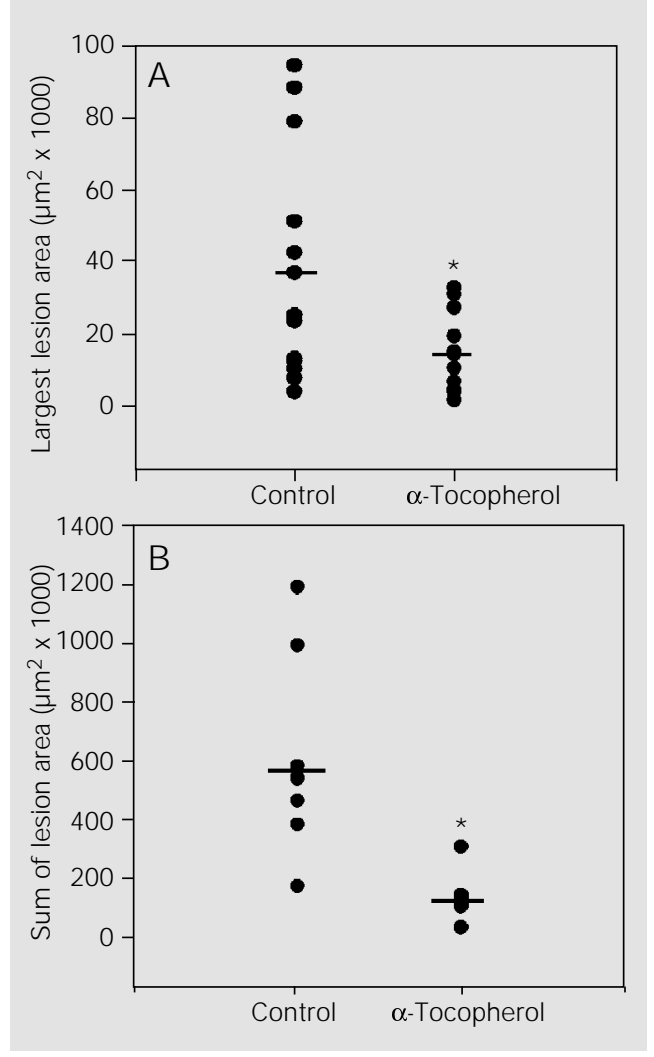

a five-fold increase in the average sum of lesion areas when compared with the $\alpha$ tocopherol group (546,115 $\pm 338,545$ and 110,203 $\pm 49,293 \mu \mathrm{m}^{2}$, respectively) (Figure 1).

When the average area of the largest lesion of each animal was considered, the lesion area was four-fold higher in the control group compared with the $\alpha$-tocopherol group (Figure 2).

Control animals had intermediate to advanced lesions with the presence of several components such as necrotic core, cholesterol clefts and fibrous cap (Figure 2A and C). $\alpha$-Tocopherol supplementation was able to reduce the lesion area as well as calcium and cholesterol deposits and necrotic core (Figure 2B and D). The predominant lesions observed in this group were fatty streaks and intermediate lesions with foam cells deposited in intima and media. Therefore, $\alpha$-tocopherol supplementation resulted in a reduction in both size and development of lesions: the necrotic core was reduced, and the calcium and cholesterol cleft depositions were impaired compared to control.

\section{Discussion}

The higher levels of $\alpha$-tocopherol in plasma of animals from the $\alpha$-tocopherol group (Table 1) confirm the efficiency of dietary supplementation with $\alpha$-tocopherol for raising the plasma levels of vitamin $\mathrm{E}$. However, the increase was not proportional to the dietary content of the vitamin. Yoshida et al. (18) isolated and characterized a tocopherol-binding protein from cytosol of rat liver. This protein may incorporate $\alpha$-tocopherol in very-low-density lipoprotein (VLDL) particles $(19,20)$. The other forms of vitamin E are similarly absorbed and reach the liver in chylomicron remnants, being excreted into the bile with excess of $\alpha$-tocopherol $(20,21)$. There is a quantitative limitation in tocopherol-binding protein incorporation of $\alpha$-tocopherol in VLDL that could be explained by the inability to raise plasma 
levels of $\alpha$-tocopherol beyond two to four times even after excessive ingestion (21). The levels found in the control group (1.22 $\mathrm{mg} / \mathrm{dl}$ or $28.37 \mu \mathrm{M}$ ) are similar to those reported by Praticò et al. (22) for a group that was not supplemented with $\alpha$-tocopherol $(1.29 \mathrm{mg} / \mathrm{dl}$ or $30 \mu \mathrm{M})$, a fact that can be explained by the similar levels of vitamin $\mathrm{E}$ in the diet $(40 \mathrm{IU} / \mathrm{kg})$.

After 6 weeks of supplementation with $\alpha$-tocopherol, the serum levels of cholesterol were similar to the control animals. Although reduction of cholesterol induced by vitamin $\mathrm{E}$ has been described in rabbits $(9,23)$ and C57BL/6 mice (24), many authors have reported no cholesterol-lowering effect of dietary vitamin E $(7,10,23,25,26)$. These reports differ from one another in many respects such as animal models, levels of dietary vitamin E, extent of supplementation, type of diets and simultaneous administration of other antioxidants - selenium, Bcarotene, and vitamin C (27-29).

Conflicting data have been reported concerning the effect of vitamin $\mathrm{E}$ on cholesterolemia in humans. Hermann et al. (30) supplemented human subjects with 600 IU of $\alpha$ tocopherol for 30 days; an increase in HDLcholesterol and no change in triglycerides or total cholesterol occurred. These results were not confirmed by other investigators who used the same experimental protocol $(31,32)$.

Data of cholesterol metabolism in apo E knockout mice are scarce. Since differences in the effect of vitamin $\mathrm{E}$ on serum cholesterol can be attributed to changes in cholesterol metabolism, we investigated cholesterol excretion and storage in liver. No differences were seen in hepatic cholesterol, its fecal catabolic products or fecal bile acids between groups.

In apo E knockout mice atherosclerosis is associated with an increase of atherogenic fractions of lipoproteins and lipid peroxidation in plasma as well as their susceptibility to peroxidation in conditions of oxidative stress (22,33-36). Knockout mice fed a com- mercial diet supplemented with 2000 IU of vitamin $\mathrm{E} / \mathrm{kg}$ for 16 weeks had significantly lower levels of isoprostanes in urine and plasma when compared with non-supplemented animals (22). The supplementation also significantly reduced the area of lesion in the aorta of knockout mice. Thus, it seems that oxidative stress may be reduced by per os administration of vitamin $\mathrm{E}$ to these mice.

These results demonstrate that supplementation with vitamin E delays the development and formation of fatty streaks in apo E-deficient animals and reinforce the hypothesis that supplementation with $\alpha$-toco-
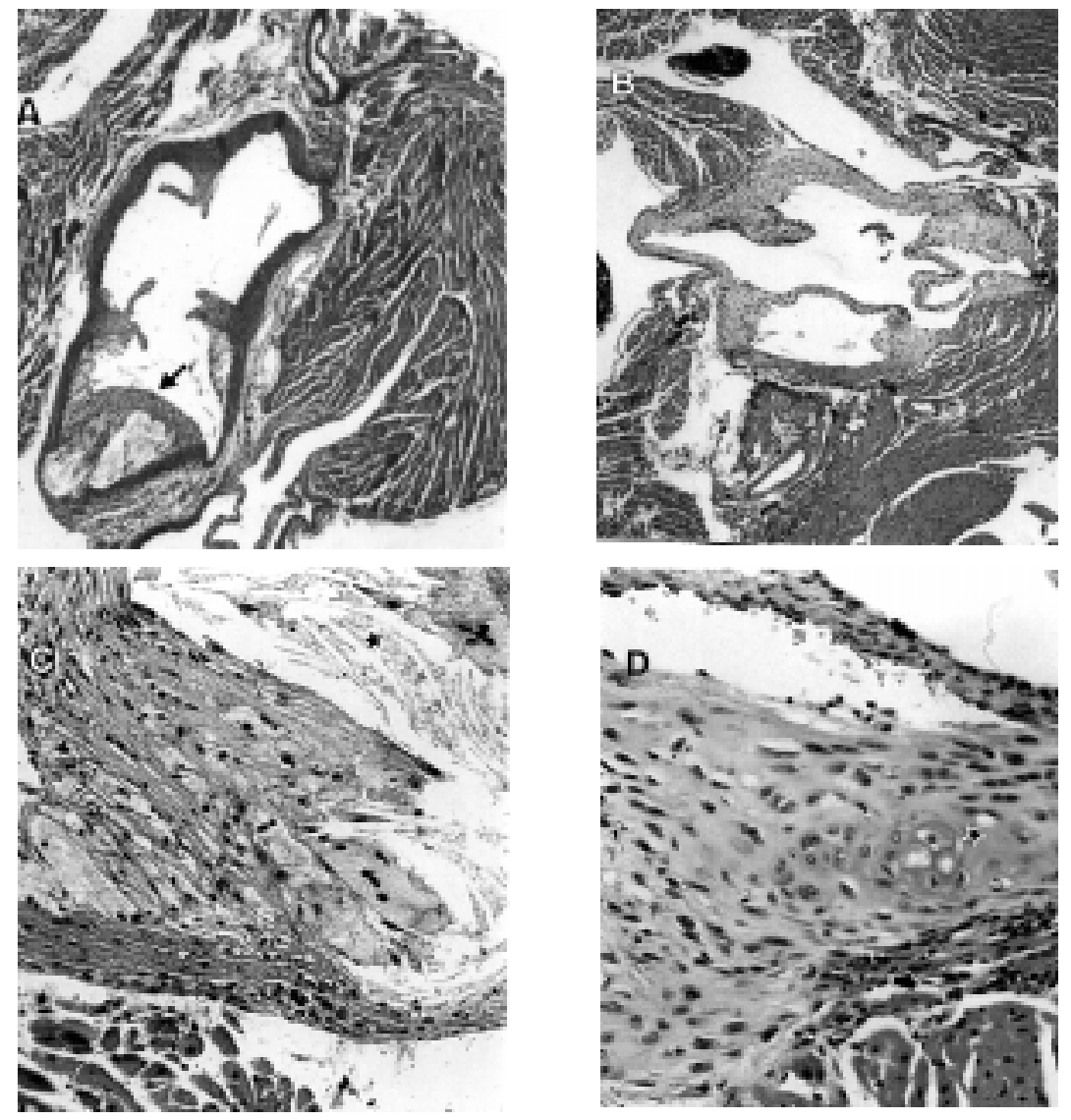

Figure 2. Histology of proximal aorta from apoE-/- mice fed diets containing $40 \mathrm{IU} / \mathrm{kg}$ (control) or $400 \mathrm{lU} / \mathrm{kg} \alpha$-tocopherol acetate for 6 weeks. A, Control group. Arrow shows an advanced lesion with a necrotic core and fibrous cap. B, $\alpha$-Tocopherol group. The lesion is less developed, composed mainly of foam cells. C, Control group, detail of Figure 2A showing necrosis area and cholesterol deposition (asterisk). D, $\alpha$-Tocopherol group, detail of Figure 2B showing a xanthomized aspect of cells (arrowhead) causing thickening of the intima. Minor areas of basophilic degeneration (asterisk) and mononuclear inflammatory infiltration among smooth muscle cells (bold arrow). Hematoxylin-eosin. Magnification: A and B, 53X; C and D, 265X. 
pherol exerts beneficial effects in terms of prevention of atherosclerosis.

\section{Acknowledgments}

We are grateful to Dr. Eder Quintão and
Dr. Marisa Passarelli (Faculdade de Medicina, USP, São Paulo, SP, Brazil), Dr. Leonides Resende Junior and Dr. Marcelo Santoro and their groups for technical support. We also thank KATAL for providing the enzymatic kits.

\section{References}

1. Keaney J r J F \& Frei B (1994). Antioxidant protection of low density lipoprotein and its role in the prevention of atherosclerotic vascular disease. In: Frei B (Editor), Natural Antioxidants in Human Health and Disease. Academic Press, San Diego, CA USA, 303-351.

2. Keaney J r J F \& Vita J (1995). Atherosclerosis, oxidative stress and antioxidant protection in endothelium-derived relaxing factor action. Progress in Cardiovascular Diseases, 2: 129-154.

3. Batlouni M (1997). Hipótese oxidativa da aterosclerose e emprego dos antioxidantes na doença arterial coronária. Arquivos Brasileiros de Cardiologia, 68: 55-62.

4. Duell PB (1996). Prevention of atherosclerosis with dietary antioxidants: fact or fiction? J ournal of Nutrition, 126: 1067S$1071 S$.

5. Wiseman H (1996). Dietary influences on membrane function: importance in protection against oxidative damage and disease. J ournal of Nutritional Biochemistry, 7: 2-15.

6. Dieber-Rotheneder M, Puhl H, Waeg G, Striegl G \& Hermann E (1991). Effect of oral supplementation with $D$ - $\alpha$-tocopherol on the vitamin $\mathrm{E}$ content of human low density lipoproteins and resistance to oxidation. J ournal of Lipid Research, 32: 1325-1332.

7. Crawford RS, Kirk EA, Rosenfeld ME, LeBoeuf RC \& Chait A (1998). Dietary antioxidants inhibit development of fatty streak lesions in the LDL receptor-deficient mouse. Arteriosclerosis, Thrombosis, and Vascular Biology, 18: 1506-1513.

8. Sun J , Giraud DW, Moxley RA \& Driskell J A (1997). ß-Carotene and $\alpha$-tocopherol inhibit the development of atherosclerotic lesions in hypercholesterolemic rabbits. International J ournal for Vitamin and Nutrition Research, 67: 155-163.

9. Williams RJ, Motteram J M, Sharp $\mathrm{CH} \&$ Gallagher PJ (1992). Dietary vitamin E and the attenuation of early lesion development in modified Watanabe rabbits. Ath- erosclerosis, 94: 153-159.

10. Fruebis J , Carew TE \& Palinski W (1995). Effect of vitamin $E$ on atherogenesis in LDL receptor-deficient rabbits. Atherosclerosis, 117: 217-224.

11. Plump AS, Smith J D, Hayek T, AaltoSetälä K, Walsh A, Verstuyft J G, Rubin EM \& Breslow J L (1992). Severe hypercholesterolemia and atherosclerosis in apolipoprotein E-deficient mice created by homologous recombination in ES cells. Cell, 71: 343-353.

12. Piedrahita JA, Zhang SH, Hagaman J R, Oliver PM \& Maeda N (1992). Generation of mice carrying a mutant apolipoprotein gene inactivated by gene targeting in embryonic stem cells. Proceedings of the National Academy of Sciences, USA, 89: 4471-4475.

13. Ueda T \& Igarashi O (1990). Determination of vitamin $E$ in biological specimens and foods by HPLC-pretreatment of samples and extraction of tocopherols. J ournal of Micronutrient Analysis, 7: 79-96.

14. Allain CC, Poon LS, Chan CS, Richmond W \& Fu PC (1974). Enzymatic determination of total serum cholesterol. Clinical Chemistry, 20: 470-475.

15. Van der Meer R, De Vries H \& Glatz J FC (1985). t-Butanol extraction of feces: a rapid procedure for enzymic determination of fecal bile acids. In: Beynen AC, Geelen MJ H, Katan MB \& Schouten J A (Editors), Cholesterol Metabolism in Health and Disease: Studies in the Netherlands. Ponsen \& Looijen, Wageningen, Netherlands, 113-137.

16. Mashige F, Tanaka N, Maki A, Kamei $S \&$ Yamanaka N (1981). Direct spectrophotometry of total bile acids in senum. Clinical Chemistry, 27: 1352-1356.

17. Folch J, Lees M \& Stanley S (1957). A simple method for the isolation and purification of total lipids from animal tissues. J oumal of Biological Chemistry, 226: 497509.

18. Yoshida H, Yusin M, Ren I, KuhlenkampJ , Hirano T, Stolz A \& Kaplowitz N (1992).
Identification, purification, and immunochemical characterization of a tocopherolbinding protein in rat liver cytosol. J ournal of Lipid Research, 33: 343-350.

19. Traber MG \& Packer L (1995). Vitamin E: beyond antioxidant function. American J ournal of Clinical Nutrition, 62: 1501S15095 .

20. Dutta-Roy AK, Gordon MJ , Campbell FM, Duthie GG \& J ames WPT (1994). Vitamin $E$ requirements, transport and metabolism: role of $\alpha$-tocopherol-binding proteins. J ournal of Nutritional Biochemistry, 5: 562-570.

21. Kayden HJ \& Traber MG (1993). Absorption, lipoprotein transport and regulation of plasma concentrations of vitamin $\mathrm{E}$ in humans. J ournal of Lipid Research, 34: 343-358.

22. Praticò $D$, Tangirala RK, Rader DJ , Rokach J \& FitzGerald GA (1998). Vitamin E suppresses isoprostane generation in vivo and reduces atherosclerosis in Apo E-deficient mice. Nature Medicine, 4: 11891192.

23. Phonpanichrasamee $C$, Komaratat $P \&$ Wilairat P (1990). Hypocholesterolemic effect of vitamin $E$ on cholesterol-fed rabbit. International J ournal for Vitamin and Nutrition Research, 60: 240-244.

24. Munday J S, Thompson KG, J ames KAC \& Manktelow BW (1998). Dietary antioxidants do not reduce fatty streak formation in the C57BL/6 mouse atherosclerosis model. Arteriosclerosis, Thrombosis, and Vascular Biology, 18: 114-119.

25. Shaish A, George J, Gilburd B, Keren P, Levkovitz H \& Harats D (1999). Dietary ßcarotene and $\alpha$-tocopherol combination does not inhibit atherogenesis in an Apo E-deficient mouse model. Arteriosclerosis, Thrombosis, and Vascular Biology, 19: 1470-1475.

26. Wojcicki J, Rozewicka L, BarcewWiszniewska B, Samochowiec L, J uzwiak S, Kadlubowska D, Tustanowski S \& J uzyszyn Z (1991). Effect of selenium and vitamin $E$ on the development of experi- 
mental atherosclerosis in rabbits. Atherosclerosis, 87: 9-16.

27. Bowry VW \& Ingold KU (1999). The unexpected role of vitamin $E$ ( $\alpha$-tocopherol) in the peroxidation of human low density lipoprotein. Archives of Chemical Research, 32: 27-34.

28. Neuzil J, Christison J K, Iheanacho E, Fragonas J C, Zammit V, Hunt $\mathrm{NH} \&$ Stocker R (1998). Radical-induced lipoprotein and plasma lipid oxidation in normal and apolipoprotein $E$ gene knockout $\left(\right.$ apoE $\left.^{-/-}\right)$mice: apoE ${ }^{-/-}$mouse as a model for testing the role of tocopherol-mediated peroxidation in atherogenesis. J ournal of Lipid Research, 39: 354-368.

29. Thomas SR, Neuzil J, Mohr D \& Stocker R (1995). Coantioxidants make $\alpha$-tocopherol an efficient antioxidant for low density lipoprotein. American J oumal of Clinical Nutrition, 62: 1357S-1364S.

30. Hermann WJ , Ward K \& Faucett J (1979). The effect of tocopherol on high-density lipoprotein cholesterol. American J ournal of Clinical Pathology, 72: 848-852.

31. Stampfer MJ, Willet W, Castelli WP, Taylor J O, Fine J \& Hennekens CH (1983). Effect of vitamin $\mathrm{E}$ on lipids. American J ournal of Clinical Pathology, 79: 714-716.

32. Howard DR, Rundell CA \& Batsakis JG (1982). Vitamin E does not modify HDLcholesterol. American J ournal of Clinical Pathology, 77: 86-89.

33. Zhang SH, Reddick RL, Piedrahita JA \& Maeda N (1992). Spontaneous hypercholesterolemia and arterial lesions in mice lacking apolipoprotein E. Science, 258: 468-471.

34. Zhang SH, Reddick RL, Burkey B \& Maeda $N$ (1994). Diet-induced atherosclerosis in mice heterozygous and homozygous for apolipoprotein E gene disruption. J ournal of Clinical Investigation, 94: 937-945.

35. Hofker MH, van Vlijmen BJ M \& Havekes LM (1998). Transgenic mouse models to study the role of APOE in hyperlipidemia and atherosclerosis. Atherosclerosis, 137: 1-11.

36. Hayek T, Oiknine J, Brook J G \& Aviram M (1994). Increased plasma and lipoprotein lipid peroxidation in Apo-E deficient mice. Biochemical and Biophysical Research Communications, 3: 1567-1574. 